\title{
Metal-Binding Ability of Human Prion Protein Fragment Peptides Analyzed by Column Switch HPLC
}

\author{
Aya Kojima, Yasunori Mabuchi, Motomi Konishi, Rika Okinara, Makoto Nagano, and \\ Toshifumi AKIZAWA* \\ Department of Analytical Chemistry, Pharmaceutical Science, Setsunan University; 45-1 Nagaotoge-cho, Hirakata, Osaka \\ 573-0101, Japan. Received February 9, 2011; accepted May 13, 2011; published online May 20, 2011
}

\begin{abstract}
The structural conversion of the prion protein $(\mathrm{PrP})$ from the normal cellular isoform $\left(\mathrm{PrP}^{\mathrm{C}}\right)$ to the posttranslationally modified form $\left(\mathrm{PrP}^{\mathrm{Sc}}\right)$ is thought to relate to $\mathrm{Cu}^{2+}$ binding to histidine $(\mathrm{H})$ residues. Traditionally, the binding of metals to PrP has been investigated by monitoring the conformational conversion using circular dichroism (CD). In this study, the metal-binding ability of 21 synthetic peptides representing regions of human $\operatorname{PrP}^{\mathrm{C}}$ was investigated by column switch high-performance liquid chromatography (CS-HPLC). The CS-HPLC system is composed of a metal chelate affinity column and an octadecylsilica (ODS) reversed-phase column that together enable the identification of metal-binding regardless of conformational conversion. Synthetic peptides were designed with respect to the position of $H$ residues as well as the secondary structure of human $\operatorname{PrP}(\mathrm{hPrP})$. The ability of the octapeptide (PHGGGWGQ)-repeating region (OP-repeat) to bind metals was analyzed by CSHPLC and supported by CD analysis, and indicated that CS-HPLC is a reliable and useful method for measuring peptide metal-binding. Peptides from the middle region of $h P r P$ showed a high affinity for $\mathrm{Cu}^{2+}$, but binding to $\mathrm{Zn}^{2+}, \mathrm{Ni}^{2+}$, and $\mathrm{Co}^{2+}$ was dependent on peptide length. $\mathrm{C}$-Terminal peptides had a lower affinity for $\mathrm{Cu}^{2+}$, $\mathrm{Zn}^{2+}, \mathrm{Ni}^{2+}$, and $\mathrm{Co}^{2+}$ than $\mathrm{OP}-$ repeat region peptides. Interestingly, hPrP193-230, which contained no $\mathrm{H}$ residues, also bound to $\mathrm{Cu}^{2+}, \mathrm{Zn}^{2+}, \mathrm{Ni}^{2+}$, and $\mathrm{Co}^{2+}$, indicating that this region is a novel metal-binding site in the C-terminal region of $\operatorname{PrP}^{\mathrm{C}}$. The CS-HPLC method described in this study is useful and convenient for assessing metal-binding affinity and characterizing metal-binding peptides or proteins.
\end{abstract}

Key words prion protein; metal-binding; metal chelate affinity column; column switch HPLC; synthetic peptide

Prion protein $(\mathrm{PrP})$ is a cell-surface glycoprotein implicated in the pathogenesis of a range of neurodegenerative disorders collectively termed transmissible spongiform encephalopathies (TSEs), including Creutzfeldt-Jakob disease (CJD) in humans, bovine spongiform encephalopathy (BSE) in cows, and chronic wasting disease (CWD) in deer. ${ }^{1-4)} \mathrm{PrP}$ exists in two distinct forms: cellular $\operatorname{PrP}\left(\operatorname{PrP}^{\mathrm{C}}\right)$ and a pathogenic or scrapie form $\left(\mathrm{PrP}^{\mathrm{Sc}}\right)$ derived from $\mathrm{PrP}^{\mathrm{C}}$. Although there is no difference in the primary structure of these isoforms, spectroscopic studies revealed that $\operatorname{PrP}^{\mathrm{C}}$ has a high $\alpha$ helical content, whereas $\mathrm{PrP}^{\mathrm{Sc}}$ is composed primarily of $\beta$ sheets. ${ }^{5,6)}$ There are many hypotheses regarding the conversion of $\operatorname{PrP}^{\mathrm{C}}$ to $\operatorname{Pr} \mathrm{P}^{\mathrm{Sc}}$, but the data suggest that conversion is entirely conformational and involves no amino acid substitutions or deletions, and thus supports the protein-only hypothesis. ${ }^{2)}$ Prion replication requires the conversion of $\mathrm{PrP}^{\mathrm{C}}$ into $\operatorname{PrP}^{\mathrm{Sc}}$, where $\mathrm{PrP}^{\mathrm{Sc}}$ acts as a template and protein $\mathrm{X}$ functions as a chaperone. ${ }^{7-9)}$

Mature human PrP (hPrP) consists of 253 amino acids, with a C-terminal glycosylphosphatidylinositol (GPI) anchor and two glycosylation sites (Fig. 1). The N-terminal domain, which includes four repeats of the PHGGGWGQ octapeptide, is a flexibly disordered region. In contrast, the C-terminal domain, which includes two $\alpha$-helices and a GPI anchor, is a folded region. The middle domain includes two $\beta$-sheets and one $\alpha$-helix. ${ }^{10-12)}$ The hPrP region spanning amino acid residues 106-126 in the middle domain is thought to be responsible for the pathogenic properties of $\operatorname{PrP}^{\mathrm{Sc}}$, including neurotoxicity, protease-resistance, induction of hypertrophy, and promotion of astrocyte proliferation. ${ }^{13-17)}$

Although PrP metal-binding sites have been investigated using full-length $\mathrm{PrP}^{\mathrm{C}}$ or synthetic fragment peptides and it is now generally accepted that $\operatorname{PrP}^{\mathrm{C}}$ binds copper in vivo, ${ }^{18)}$ most researchers have focused on the octarepeat region, ${ }^{19-23)}$ and there are few reports describing the metal-binding ability of the middle- and C-terminal domains of hPrP. ${ }^{24)}$ The interaction of full-length and truncated forms of $\operatorname{PrP}$ with $\mathrm{Cu}^{2+}$ has been investigated using a range of techniques, including electron paramagnetic resonance (EPR), ${ }^{25-27)}$ circular dichroism (CD), ${ }^{28,29)}$ X-ray crystallography ${ }^{30)} \mathrm{NMR}^{31,32)}$ MS, ${ }^{33-35)}$ Raman spectroscopy, ${ }^{36,37)}$ Fourier transform infrared (FT-IR) spectroscopy, ${ }^{38)}$ and potentiometry. ${ }^{39)}$ Although these methods have been useful, most can only detect metal-binding that occurs during conformational conversion, and as a result, they cannot detect metal-binding occurring without conformational conversion. Only MS is capable of detecting metal-binding that does not occur in conjunction with conformational conversion. Electrospray ionization (ESI)-MS has the advantage of being able to provide speciation information directly, and has been used to analyze $\mathrm{Cu}^{2+}$ binding to $\mathrm{hPrP}$ octarepeat peptides. ${ }^{40,41)}$

We developed a column switch (CS)-HPLC system that can detect direct metal-binding to the octarepeat region of $\mathrm{hPrP}^{\mathrm{C}}$, and the data obtained using our CS-HPLC method agreed well with previous $\mathrm{CD}$ analyses. ${ }^{42,43)}$ In this study, we used CS-HPLC to analyze the metal-binding characteristics of 21 synthetic fragment peptides derived from the sequence of $\mathrm{hPrP}$ amino acids $60-230$.

\section{Experimental}

Materials Trifluoroacetic acid (TFA) (Peptide Synthesis Grade), diethyl ether, acetonitrile $\left(\mathrm{CH}_{3} \mathrm{CN}\right.$, HPLC grade), 2-amino-2-hydroxymethyl-1, 3propandiol (Tris), $\mathrm{HgCl}_{2}, \mathrm{ZnCl}_{2}, \mathrm{MnCl}_{2} \cdot 4 \mathrm{H}_{2} \mathrm{O}, \mathrm{CaCl}_{2} \cdot 2 \mathrm{H}_{2} \mathrm{O}$, and $\mathrm{CoCl}_{2}$ $6 \mathrm{H}_{2} \mathrm{O}$ were purchased from Wako Pure Chemical Industries, Ltd., Inc. (Japan). Thioanisole, $\mathrm{CuCl}_{2} \cdot 2 \mathrm{H}_{2} \mathrm{O}, \mathrm{CdCl}_{2} \cdot 21 / 2 \mathrm{H}_{2} \mathrm{O}$, and $\mathrm{NiCl}_{2} \cdot 6 \mathrm{H}_{2} \mathrm{O}$ were obtained from Nacalai Tesque (Japan). 1,2-Ethandithiol and $\mathrm{AlCl}_{3} \cdot 6 \mathrm{H}_{2} \mathrm{O}$ were obtained from Kanto Chemical Co., Inc. (Japan). Ethylenediaminetetraacetic acid disodium salt dihydrate (EDTA-2Na) and $\mathrm{HCl}$ were purchas- 
ed from Kishida Chemical Co., Ltd. (Japan). Piperidine was obtained from Sigma-Aldrich Japan (Japan). O-(7-Azabenzo-triazol-1-yl)- $N, N, N^{\prime}, N^{\prime}$-tetramethyluronium hexafluoro-phosphate (HATU), $N, N$-dimethylformamide, $2.0 \mathrm{M} N, N$-diisopropylethylamine/ $N$-methylpyrrolidone (DIEA), dichloromethane, $N$-methylpyrrolidone, preloaded resin fluorenylmethoxycarbonyl (Fmoc)-L-Asn (Trt), preloaded resin Fmoc-L-Asp (OtBu), preloaded resin Fmoc-L-Cys (Trt), preloaded resin Fmoc-L-Glu (OtBu), preloaded resin Fmoc-L-Gln (Trt), preloaded resin Fmoc-L-Gly, preloaded resin Fmoc-L-Lys (Boc), preloaded resin Fmoc-L-Ser (tBu), preloaded resin Fmoc-L-Thr (tBu), and preloaded resin Fmoc-L-Val were purchased from Applied Biosystems (ABI, div. Perkin Elmer, U.S.A.). Fmoc-L-Ala, Fmoc-L-Arg (Pmc), Fmoc-LAsn (Trt), Fmoc-L-Asp (OtBu), Fmoc-L-Cys (Trt), Fmoc-L-Gln (Trt), FmocL-Glu (OtBu), Fmoc-L-Gly, Fmoc-L-His (Trt), Fmoc-L-Ile, Fmoc-L-Leu, Fmoc-L-Lys (Boc), Fmoc-L-Met, Fmoc-L-Pro, Fmoc-L-Phe, Fmoc-L-Ser (tBu), Fmoc-L-Thr (tBu), Fmoc-L-Trp (Boc), Fmoc-L-Tyr (tBu), and Fmoc-LVal were obtained from ABI, AAPPTec, LLC (U.S.A.) and Peptide Institute, Inc. (Japan). Milli-Q water was used for all experiments.

Peptide Synthesis Fragment peptides corresponding to amino acid sequence from human prion protein were synthesized using an automated $\mathrm{ABI}$ model $433 \mathrm{~A}$ peptide synthesizer $(0.1 \mathrm{mmol}$ scale with preloaded resin) from Fmoc protected L-amino acid derivatives purchased from $\mathrm{ABI}^{44,45)}$ Amino acids were preactivated by reaction with HATU and DIEA. After deprotection according to the manufacturer's protocol, each peptide was purified using reversed-phase HPLC (Capcell Pak C18 column, SG, 10 or $15 \mathrm{~mm}$ i.d. $\times 250 \mathrm{~mm}$; Shiseido Co., Ltd., Japan) with a linear gradient elution from $0.1 \%$ TFA to $50 \%$ or $70 \% \mathrm{CH}_{3} \mathrm{CN}$ containing $0.1 \%$ TFA over $30 \mathrm{~min}$. The primary peak was collected and then lyophilized. Peptide purity was confirmed using an analytical HPLC system as described below. Each purified peptide was characterized by ESI-MS using a Qstar Elite Hybrid LC/MS/MS system (ABI).

Analytical HPLC Cleavage reactions and the purity of synthetic peptides were confirmed by analytical reversed-phase HPLC (Cosmosil 5C $\mathrm{C}_{18}$ AR-II column, $5 \mu \mathrm{m}, 4.6 \mathrm{~mm}$ i.d. $\times 150 \mathrm{~mm}$; Nacalai Tesque, Japan) with a flow rate of $1.0 \mathrm{ml} / \mathrm{min}$ and a linear gradient elution from $0.1 \%$ TFA to $70 \%$ $\mathrm{CH}_{3} \mathrm{CN}$ containing $0.1 \%$ TFA. The column eluate was monitored with a photodiode-array detector (SPD-M20A; Shimadzu, Japan).

Column Switch (CS)-HPLC System The CS-HPLC method used here was modified from the method reported previously, ${ }^{46)}$ and consisted of an affinity column (TSKgel Chelate-5PW, $75 \mathrm{~mm} \times 7.5 \mathrm{~mm}$ i.d.; Tosoh, Japan) for the first separation and an octadecylsilica (ODS) reversed-phase column (Cosmosil 5C $\mathrm{C}_{18}$-MS-II, $150 \mathrm{~mm} \times 4.6 \mathrm{~mm}$ i.d.; Nacalai Tesque, Japan) for the second separation. The time schedules for column switching are described in Fig. 2. The flow rate was set at $1.0 \mathrm{ml} / \mathrm{min}$ for the first separation, and the eluate was monitored by UV absorption at 220 or $280 \mathrm{~nm}$ (Detector 1). The affinity column was flushed with $3 \mathrm{~mm}$ metal solution for $10 \mathrm{~min}$ (total $30 \mu \mathrm{mol})$ and then washed with binding buffer $(20 \mathrm{~mm}$ Tris- $\mathrm{HCl}(\mathrm{pH} 8.0)$ containing $500 \mathrm{~mm} \mathrm{NaCl}$ ) for $15 \mathrm{~min}$ before sample injection. Various peptide samples were loaded onto the affinity column, and then the column was washed with binding buffer for $10 \mathrm{~min}$ to allow for peptide binding. The solvent was then changed to $20 \mathrm{~mm}$ Tris- $\mathrm{HCl}$ ( $\mathrm{pH} 8.0$ ) containing $500 \mathrm{~mm} \mathrm{NaCl}$ and $50 \mathrm{~mm}$ EDTA (elution buffer) using a solvent selection unit in manual mode. At the same time, a column selection unit was manually switched, and the eluate from the affinity column was directed to the second in-line reversed-phase HPLC column for $10 \mathrm{~min}$. The reversed-phase column was then flushed with $0.1 \%$ TFA for 5 min to remove residual elution buffer, and peptides were then eluted with a linear gradient from $0.1 \%$ TFA to $50 \%$ or $70 \% \mathrm{CH}_{3} \mathrm{CN}$ containing $0.1 \%$ TFA for $15 \mathrm{~min}$. The flow rate of the second column was $1.0 \mathrm{ml} / \mathrm{min}$, and the chromatogram was monitored by $\mathrm{UV}$ absorption at 220 or $280 \mathrm{~nm}$ (Detector 2).

CD Analysis CD spectroscopy was carried out at room temperature in a J-805 spectropolarimeter (Jasco, Japan) continuously flushed with dry nitrogen, using a circular quartz cell with a path length of $0.2 \mathrm{~cm}$. The peptide concentration was $10 \mu \mathrm{M}$ in $10 \mathrm{~mm}$ Tris- $\mathrm{HCl}$ buffer at $\mathrm{pH} 6.0,6.5,7.0,7.5$, or 8.0. The concentration of $\mathrm{Cu}^{2+}$ was equivalent to twice the number of $\mathrm{H}$ residues. The wavelength range was restricted to over $195 \mathrm{~nm}$ due to excessive absorption by the buffer at lower wavelengths. Data are presented from triple scans with subtraction of buffer spectra and mathematical smoothing.

\section{Results and Discussion}

Preparation of Synthetic Fragment Peptides The amino acid sequences of synthetic peptides in this study were selected on the basis of the position of $\mathrm{H}$ residues and the secondary structure of hPrP. ${ }^{11)}$ The domain structure of hPrP

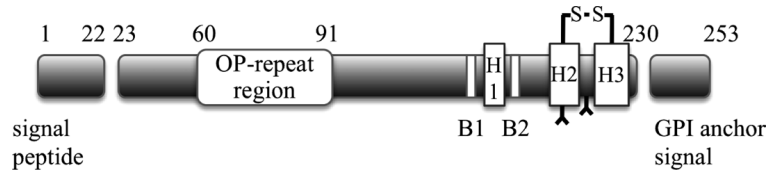

Fig. 1. Domain Structure of Human Prion Protein

$\mathrm{B} 1, \beta$-sheet region (hPrP 128-131); B2, $\beta$-sheet region (hPrP 161-164); H1, $\alpha$ helix region (hPrP 144-154); H2, $\alpha$-helix region (hPrP 173-194); H3, $\alpha$-helix region (hPrP 200-228); S-S, disulfide bond; 人, N-type glycosylation.

is illustrated in Fig. 1, and the peptides used in this study are listed in Table 1. We divided hPrP residues $60-230$ into the following 3 domains in this study; hPrP60-91 as the octapeptide repeat region (OP-repeat), hPrP92-168 as the middle domain, and hPrP169-230 as the C-terminal domain. Synthetic fragment peptides of various lengths covered $\mathrm{hPrP}$ residues $60-230$. The synthetic ratio appeared to be very high, and the purity of the synthetic peptides was sufficient for using in this study. All peptides were characterized by ESI-MS using a direct spray method.

OP-repeat, composed of four highly conserved, contiguous repeats of the eight-residue sequence PHGGGWGQ, is located in the flexible N-terminal region of hPrP. This domain also contains the copper-binding sites. Four peptides corresponding to sequences in $\mathrm{hPrP}$ and containing one to four octarepeats were synthesized to confirm the reliability of the CS-HPLC system for measuring the binding of various metals. The peptide PAGGGWGQ, containing an $\mathrm{H}$ residue to A residue substitution, was synthesized to serve as a negative control for the octapeptide. We also synthesized an additional eight fragment peptides corresponding to the middle domain of hPrP (amino acids 92-168), each of which contained one to three $\mathrm{H}$ residues. In addition, five $\mathrm{H}$-containing peptides and three non-H-containing peptides corresponding to the $\mathrm{C}$ terminal domain of hPrP (amino acids 169-230) were synthesized and characterized in the same manner described above. The amino acid sequences of the synthetic peptides examined in this study are listed in Table 1.

CS-HPLC System The binding ability of metals to hPrP peptides was assessed using a CS-HPLC system. The CSHPLC system consisted of a chelate affinity column and a reversed-phase column for the first and second separations, respectively. The column switching schedule used in the total analysis and binding analysis are shown in Fig. 2. An initial CS-HPLC experiment was carried out without loading any sample as a prerun to equilibrate the columns. For total analysis, the chelate column was washed with Tris buffer for $10 \mathrm{~min}$ and then washed with Tris-EDTA buffer for an additional $10 \mathrm{~min}$ after sample injection. In this process, no metal bound to the chelate column; therefore, peptides were loaded onto an ODS column directly and trapped. The column selection unit was switched to line B 20 min after sample injection. The ODS column was washed with $0.1 \%$ TFA for $5 \mathrm{~min}$ to wash out the buffer carried over from the first column, and then the second column was performed with a linear gradient elution system.

The chromatogram for the total analysis of $\mathrm{Cu}^{2+}$ binding to peptide OP-4 is shown in Figs. $3 a$ and b. The affinity of metal-binding was measured according to the binding analysis method shown in Fig. 2. In the binding analysis, individual metal ions were loaded onto the chelate affinity column 
for $10 \mathrm{~min}$ during the prerun. After sample injection, the chelate column was washed with Tris buffer for $10 \mathrm{~min}$, after which the buffer was changed to Tris-EDTA. Peptides eluted from the chelate column were then directly loaded onto the reversed-phase ODS column in an in-line fashion. The same analytical procedure was used in the total analysis method.

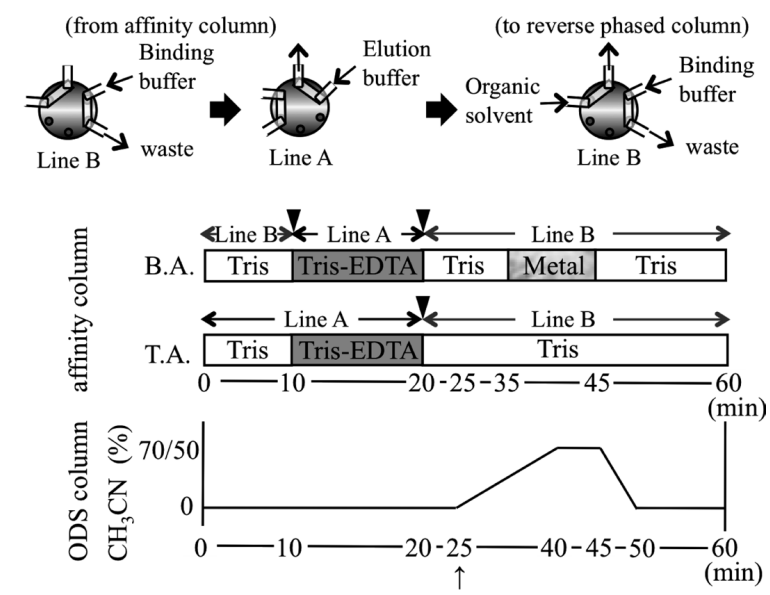

Fig. 2. Condition of Column Switch HPLC System

$\boldsymbol{\nabla}$ : Column selecting point. $\uparrow:$ Analysis starting point. B.A.: Binding analysis. T.A.: Total analysis.
The chromatograms for the binding analysis for $\mathrm{Cu}^{2+}$ binding to peptide OP-4 are shown in Figs. $3 \mathrm{c}$ and d. Based on these data, the $\mathrm{Cu}^{2+}$-binding ability was calculated.

Binding of Various Metals to the Octarepeat Region in the N-Terminal Domain of hPrP (Amino Acids 60-91) The OP-repeat, composed of four highly conserved, contiguous repeats of the eight-residue sequence PHGGGWGQ, is located in the flexible N-terminal region of hPrP. This domain functions as the $\mathrm{Cu}^{2+}$-binding site.

The chromatograms for the total and binding analysis of $\mathrm{Cu}^{2+}$ to peptide OP-4 are shown in Fig. 3. In the total analysis, OP-4 eluted from the chelate column with a shorter retention time than it eluted from the ODS column (Figs. $3 a, b)$, indicating that the peptide did not bind to the chelate column. On the other hand, in the binding analysis, there is no peak on the chromatogram for the chelate column at the earlier retention time (Fig. 3c), but the same peak was identified eluting from the ODS column that eluted from the ODS column in the total analysis (Fig. 3d). Taken together, the data indicate that $\mathrm{Cu}^{2+}$ bound to the peptide, and we calculated the binding ratio as $98.8 \%$ by comparing the peak areas from both analyses. Although OP-1 showed the similar chromatogram patterns to those of OP-4 in the total analysis (Fig. $3 e, f)$, however, no peak was appeared in the binding analysis of OP-1 (Fig. 3h). These data indicate that OP-1 did not bind

Table 1. Amino Acid Sequences of Human Prion Protein-Derived Fragment Pepteides

\begin{tabular}{|c|c|c|}
\hline Name & Region & Sequence \\
\hline $60-91(\mathrm{OP}-4)$ & $\mathrm{OP}$ & PHGGGWGQPHGGGWGQPHGGGWGQPHGGGWGQ \\
\hline $60-83(\mathrm{OP}-3)$ & $\mathrm{OP}$ & PHGGGWGQPHGGGWGQPHGGGWGQ \\
\hline $60-75(\mathrm{OP}-2)$ & OP & PHGGGWGQPHGGGWGQ \\
\hline $60-67(\mathrm{OP}-1)$ & OP & PHGGGWGQ \\
\hline OP-1/HA & OP & PAGGGWGQ \\
\hline $92-168$ & $\alpha+2 \beta+$ un & GGGTHSQWNKPSKPKTNMKHMAGAAAAGAVVGGLGGYMLGSAMSRPIIHFGSDYEDRYYRENMHRYPNQVYYRPMDE \\
\hline $119-168$ & $\alpha+2 \beta+$ un & GAVVGGLGGYMLGSAMSRPIIHFGSDYEDRYYRENMHRYPNQVYYRPMDE \\
\hline $134-168$ & $\alpha+\beta+$ un & MSRPIIHFGSDYEDRYYRENMHRYPNQVYYRPMDE \\
\hline $148-168$ & $\alpha+\beta$ & RYYRENMHRYPNQVYYRPMDE \\
\hline $92-106$ & un & GGGTHSQWNKPSKPK \\
\hline $107-119$ & un & TNMKHMAGAAAAG \\
\hline $132-144$ & un & SAMSRPIIHFGSD \\
\hline $150-159$ & $\alpha+$ un & YRENMHRYPN \\
\hline $169-192$ & $\alpha+$ un & YSNQNNFVHDCVNITIKQHTVTTT \\
\hline $169-179$ & $\alpha+$ un & YSNQNNFVHDC \\
\hline $169-178$ & $\alpha+$ un & YSNQNNFVHD \\
\hline $175-189$ & $\alpha$ & FVHDCVNITIKQHTV \\
\hline $180-192$ & $\alpha$ & VNITIKQHTVTTT \\
\hline 180-192/HA & $\alpha$ & VNITIKQATVTTT \\
\hline $193-230$ & $\alpha+$ un & TKGENFTETDVKMMERVVEQMCITQYERESQAYYQRGS \\
\hline $215-230$ & $\alpha+$ un & ITQYERESQAYYQRGS \\
\hline
\end{tabular}

$\alpha$ : $\alpha$-helix, $\beta$ : $\beta$-sheet, un: unstructured, OP: octarepeat.

Table 2. Metal-Biding Ability of OP-Repeat Region

\begin{tabular}{|c|c|c|c|c|c|c|c|c|c|}
\hline Name & $\mathrm{Cu}^{2+}$ & $\mathrm{Zn}^{2+}$ & $\mathrm{Ni}^{2+}$ & $\mathrm{Co}^{2+}$ & $\mathrm{Mn}^{2+}$ & $\mathrm{Ca}^{2+}$ & $\mathrm{Cd}^{2+}$ & $\mathrm{Hg}^{2+}$ & $\mathrm{Al}^{3+}$ \\
\hline $60-91(\mathrm{OP}-4)$ & ++ & ++ & ++ & ++ & - & - & \pm & - & - \\
\hline $60-83(\mathrm{OP}-3)$ & ++ & ++ & ++ & ++ & - & - & - & - & - \\
\hline $60-75(\mathrm{OP}-2)$ & ++ & ++ & ++ & ++ & - & - & - & - & - \\
\hline $60-67(\mathrm{OP}-1)$ & - & ++ & ++ & - & - & - & - & - & - \\
\hline $\mathrm{OP}-1 / \mathrm{HA}^{a}$ & - & & & & & & & & \\
\hline
\end{tabular}

$++: 80 \%<$ Recovery $\%$. +: $79>$ Recovery $\%>11 \% . \pm: 10>$ Recovery $\%>2 \%$. - : Recovery $\%<2 \%$. a) Substituted peptide of His with $\mathrm{Ala} \mathrm{Cu}^{2+}, \mathrm{CuCl}_{2} ; \mathrm{Zn}^{2+}, \mathrm{ZnCl}_{2} ; \mathrm{Ni}^{2+}$, $\mathrm{NiCl}_{2} ; \mathrm{Co}^{2+}, \mathrm{CoCl}_{2} ; \mathrm{Mn}^{2+}, \mathrm{MnCl}_{2} ; \mathrm{Ca}^{2+}, \mathrm{CaCl}_{2} ; \mathrm{Cd}^{2+}, \mathrm{CdCl}_{2} ; \mathrm{Hg}^{2+}, \mathrm{HgCl}_{2} ; \mathrm{Al}^{3+}, \mathrm{AlCl}_{3}$. 
a)

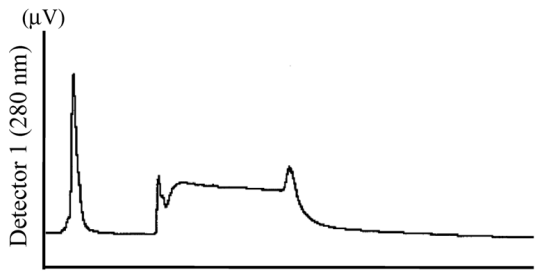

b)

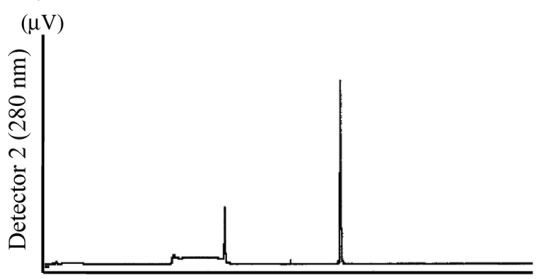

c)

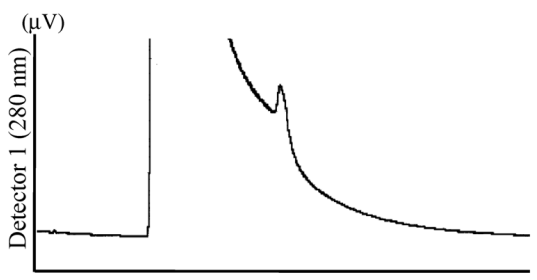

d)

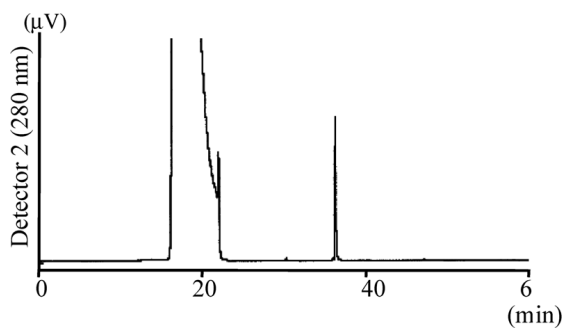

e)

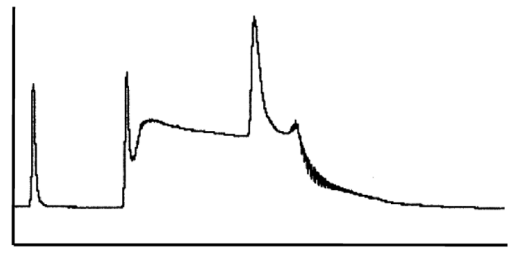

f)

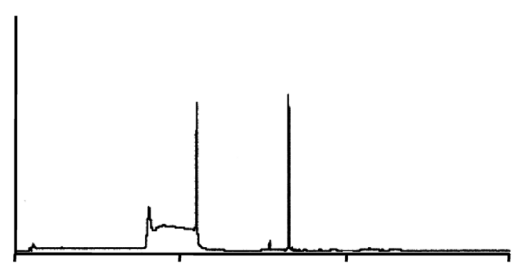

g)

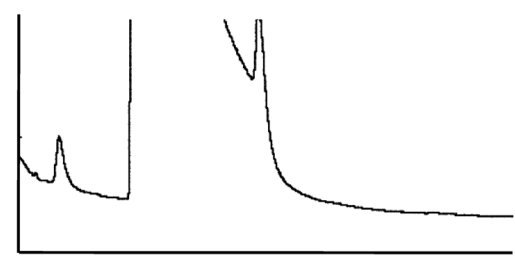

h)

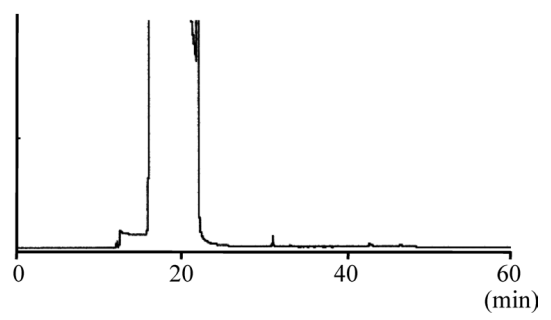

Fig. 3. Chromatograms of $\mathrm{Cu}^{2+}$-Binding to OP-4 Using Column Switch HPLC

a) Total analysis of OP-4 by metal-chelate column. b) Total analysis of OP-4 by column. c) Binding analysis of OP-4 by metal-chelate column. d) Binding analysis of OP-4 by ODS column. e) Total analysis of OP-1 by metal-chelate column. f) Total analysis of OP-1 by ODS column. g) Binding analysis of OP-1 by metal-chelate column. h) Binding analysis of OP-1 by ODS column.

to the chelate affinity column.

The binding of other metals to the synthetic peptides was analyzed in the same manner. The metal-binding ability of peptides OP-1 to OP-4 is listed in Table 2. All metal ions tested here showed a similar affinity for OP-2, OP-3, and OP4 , except that $\mathrm{Cd}^{2+}$ bound to OP-4 with a weak affinity. These data agree well with $\mathrm{CD}$ analyses of the metal-binding ability of both a previous report ${ }^{29)}$ and our CD data (data not shown). In addition, $\mathrm{OP}-1 / \mathrm{HA}$, containing an $\mathrm{H}$ residue to $\mathrm{A}$ residue substitution, had a poor binding affinity for $\mathrm{Cu}^{2+}$. Therefore, we concluded that CS-HPLC is a reliable method for measuring the binding of various metals to fragment peptides of $\mathrm{PrP}^{\mathrm{C}}$. Interestingly, we also found that $\mathrm{Cu}^{2+}$ and $\mathrm{Co}^{2+}$ did not bind to OP-1, which is composed of only one octapeptide region.

Binding of Metals to Peptides Representing the Middle Domain of hPrP (Amino Acids 92-168) The majority of metal-binding studies to date have focused on the OP-repeat region, with few reports describing the binding of metals to peptides representing the middle- and C-terminal regions of hPrP. The so-called "fifth binding site," containing amino acids H96 and H111, is located on the C-terminal side of the OP-repeat region and is thought to be a binding site for $\mathrm{Cu}^{2+}$. In addition, there are many $\mathrm{H}$ and $\mathrm{M}$ residues in the $\mathrm{hPrP}$ region spanning residues $92-168$ to which various metal ions could bind. Since we had demonstrated the reliability of CSHPLC to assess binding of metals to hPrP peptides (see Table 2), we then assessed the binding of various metals to eight fragment peptides representing the middle domain of $\mathrm{PrP}^{\mathrm{C}}$ using CS-HPLC (Table 3).

The chromatograms for $\mathrm{Co}^{2+}$-binding to the hPrP92-168 and hPrP148 - 168 regions are shown in Fig. 4. In the case of hPrP92 - 168, the chromatogram from the ODS column obtained in the total analysis (Fig. 4a) was same as that obtained in the binding analysis (Fig. 4b), indicating that $\mathrm{Co}^{2+}$ bound to hPrP92 - 168. The binding ratio was calculated as $91.3 \%$ by comparison of both peak areas. Region hPrP92 168 possessed a potent binding affinity for $\mathrm{Cu}^{2+}, \mathrm{Zn}^{2+}, \mathrm{Ni}^{2+}$, 
a)

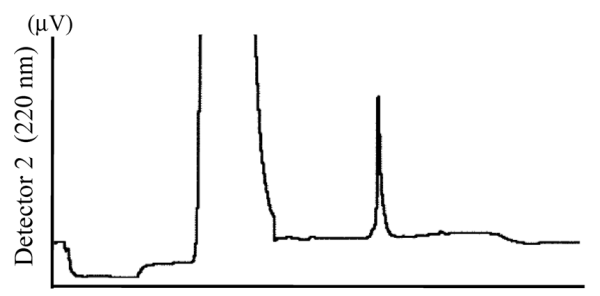

b)

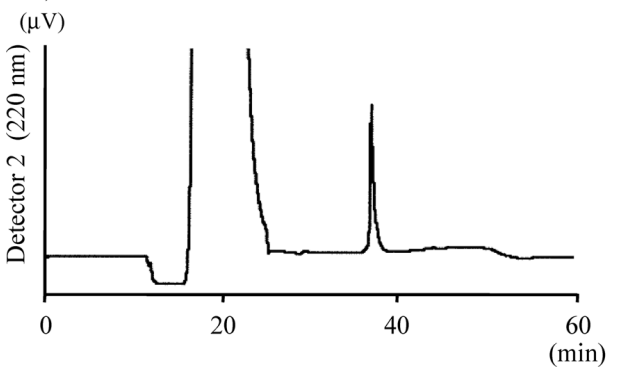

c)

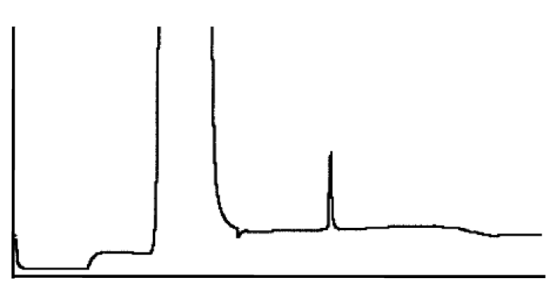

d)

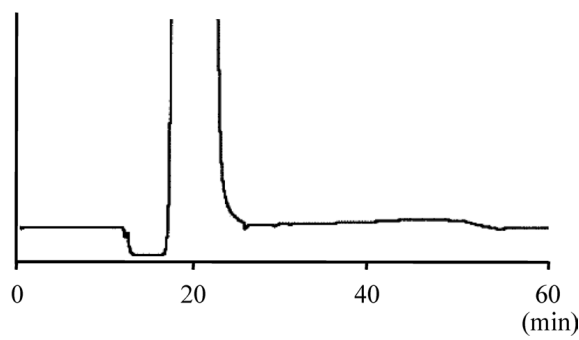

Fig. 4. Chromatograms of $\mathrm{Co}^{2+}$-Binding to hPrP92-168 and hPrP148-168 Obtained from ODS Column

a) Total analysis of hPrP92 - 168. b) Binding analysis of hPrP92 - 168. c) Total analysis of hPrP148-168. d) Binding analysis of hPrP148-168.

a)

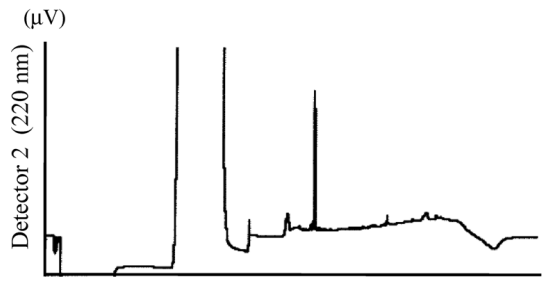

b)

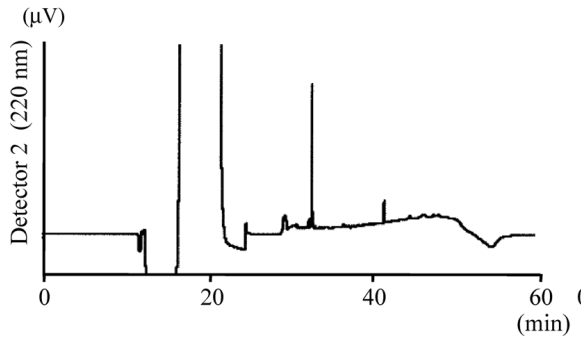

c)

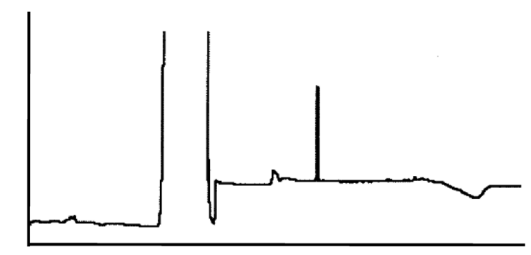

d)

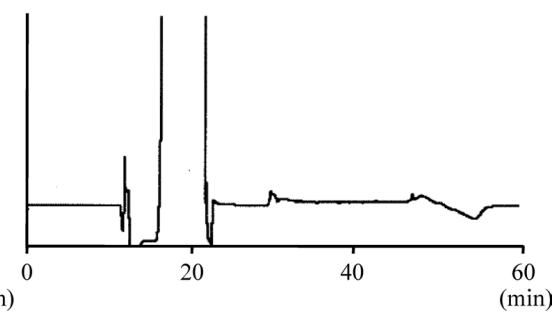

Fig. 5. Chromatograms of $\mathrm{Cu}^{2+}$-Binding to hPrP180-192 and hPrP180-192/HA Obtained from ODS Column

a) Total analysis of hPrP180 - 192. b) Binding analysis of hPrP180 - 192. c) Total analysis of hPrP180-192/HA. d) Binding analysis of hPrP180-192/HA.

and $\mathrm{Co}^{2+}$ (Table 3).

Cobalt bound to the hPrP148-168 region differently than it bound to the hPrP92-168 region. As shown in Fig. 4, the peak appearing at $35.78 \mathrm{~min}$ on the total analysis chromatogram for hPrP148-168 (Fig. 4c) was not identified in the binding analysis chromatogram (Fig. 4d).

The ability of various metals to bind to eight peptides representing the hPrP92-168 region is shown in Table 3. All peptides tested here possessed a potent binding affinity for $\mathrm{Cu}^{2+}$. In general, the longer peptides showed a higher affinity for $\mathrm{Zn}^{2+}, \mathrm{Ni}^{2+}$, and $\mathrm{Co}^{2+}$, as well as $\mathrm{Cu}^{2+}$, while shorter peptides had a higher affinity only for $\mathrm{Cu}^{2+}$. For example, hPrP92 - 168, which is the longest peptide and consists of 77 amino acids, possessed high affinity for $\mathrm{Cu}^{2+}, \mathrm{Zn}^{2+}, \mathrm{Ni}^{2+}$, and $\mathrm{Co}^{2+}$ (Table 3); however, no conformational conversion was observed upon $\mathrm{Cu}^{2+}$ binding by $\mathrm{CD}$ analysis at $\mathrm{pH} 6.0$, $6.5,7.0,7.5$, or 8.0 (data not shown). These data indicate that CS-HPLC is a useful method for analyzing the binding of metals to peptides regardless of conformational conversion.

Binding of Metals to Peptides Representing the C-Terminal Domain of hPrP (Amino Acids 169-230) The Cterminal domain is thought to be responsible for the aggregation of PrP; however, there are few reports regarding the binding of metals to peptides in this domain. Therefore, we examined the binding of metals to eight peptides representing the C-terminal domain of hPrP (amino acids 169-230).

The chromatograms for the binding of $\mathrm{Cu}^{2+}$ to peptides hPrP180-192 and hPrP180-192/HA are shown in Fig. 5. 
a)

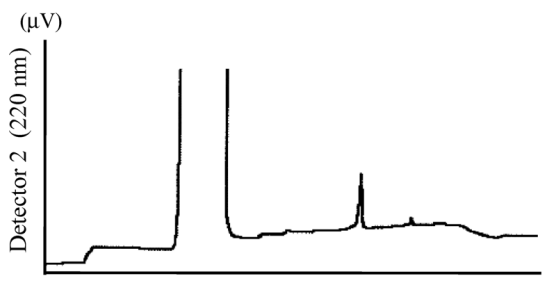

b)

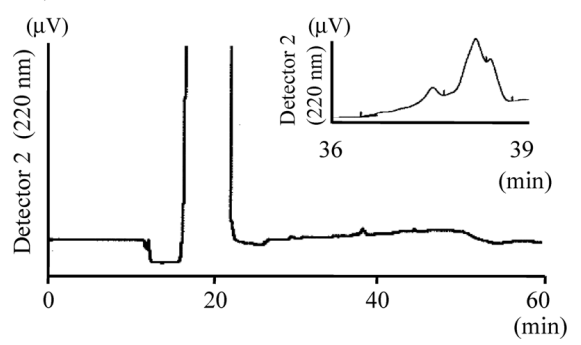

c)

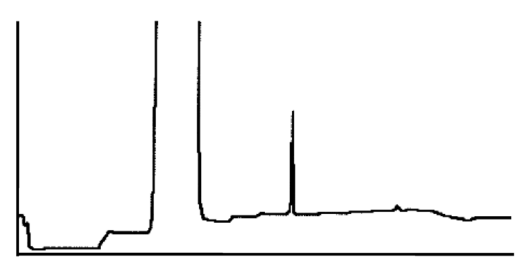

d)

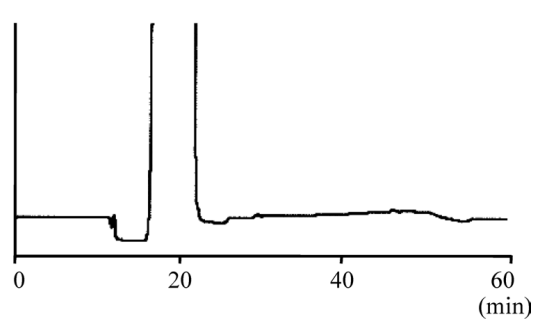

Fig. 6. Chromatograms of $\mathrm{Cu}^{2+}$-Binding to hPrP193-230 and hPrP215-230 Obtained from ODS Column

a) Total analysis of hPrP193 - 230. b) Binding analysis of hPrP193 - 230. c) Total analysis of hPrP215 - 230. d) Binding analysis of hPrP215-230.

Table 3. Metal-Binding Ability of Middle and C-Terminal Regions

\begin{tabular}{|c|c|c|c|c|}
\hline Name & $\mathrm{Cu}^{2+}$ & $\mathrm{Zn}^{2+}$ & $\mathrm{Ni}^{2+}$ & $\mathrm{Co}^{2+}$ \\
\hline $92-168$ & ++ & ++ & ++ & ++ \\
\hline $119-168$ & ++ & ++ & ++ & + \\
\hline $134-168$ & ++ & ++ & ++ & + \\
\hline $148-168$ & ++ & ++ & ++ & - \\
\hline $92-106$ & ++ & - & ++ & - \\
\hline $107-119$ & ++ & - & - & - \\
\hline $132-144$ & ++ & - & - & - \\
\hline $150-159$ & ++ & \pm & ++ & - \\
\hline $169-192$ & N.D. & N.D. & N.D. & N.D. \\
\hline $169-179$ & + & + & + & \pm \\
\hline $169-178$ & + & - & + & - \\
\hline $175-189$ & + & + & + & + \\
\hline $180-192$ & ++ & - & - & - \\
\hline $180-192 / \mathrm{HA}^{a)}$ & - & & & \\
\hline $193-230^{b)}$ & + & + & + & + \\
\hline $215-230^{b)}$ & - & - & - & - \\
\hline
\end{tabular}

$++: 80 \%<$ Recovery $\% .+: 79>$ Recovery $\%>11 \%$. $\pm: 10>$ Recovery $\%>2 \%$. Recovery $\%<2 \%$. a) Substituted peptide of His with Ala. b) hPrP193-230 and hPrP215-230 did not contain His residue. $\mathrm{Cu}^{2+}, \mathrm{CuCl}_{2} ; \mathrm{Zn}^{2+}, \mathrm{ZnCl}_{2} ; \mathrm{Ni}^{2+}, \mathrm{NiCl}_{2}$ $\mathrm{Co}^{2+}, \mathrm{CoCl}_{2}$.

The same peak was identified eluting at the same retention time on the ODS column in both the total and binding analyses (Figs. 5a, b). The peak for peptide hPrP180-192/HA, in which an $\mathrm{A}$ residue has been substituted for the $\mathrm{H}$ residue, was not identified by the binding analysis (Figs. 5c, d). These data indicate that the ability of hPrP180 - 192 to bind metal is due to the $\mathrm{H}$ residue. In contrast, hPrP193 - 230, which does not contain an $\mathrm{H}$ residue but contains three $\mathrm{M}$ residues and one $\mathrm{C}$ residue, bound weakly to all metal ions tested. Peptide hPrP215-230, in which the N-terminal region encompassing the $\mathrm{M}$ and $\mathrm{C}$ residues of peptide hPrP193-230 had been deleted, did not show affinity to any metal ions tested (Fig. 6, Table 3). These data suggest that the $\mathrm{M}$ and $\mathrm{C}$ residues are responsible for the ability to bind metals, similarly to the $\mathrm{H}$ residue. Although hPrP169-179 possessed affinity for $\mathrm{Cu}^{2+}, \mathrm{Zn}^{2+}$, and $\mathrm{Ni}^{2+}$, deleting the $\mathrm{C}$ from
hPrP169-179 (peptide hPrP169-178) resulted in a loss of binding affinity for $\mathrm{Zn}^{2+}$, suggesting that the $\mathrm{C}$ residue in this region may be the $\mathrm{Zn}^{2+}$-binding site in $\mathrm{PrP}^{\mathrm{C}}$.

Of the 21 peptides tested here, we were unable to examine the metal-binding ability of one, peptide hPrP169-192, because the identical peak was not found in chromatograms from both the total analysis and binding analysis. The data are interesting and suggest that hPrP169-192 may have been tightly bound to the chelate column in a nonspecific manner.

\section{Conclusion}

The CS-HPLC method described in this study is useful and convenient for assessing the metal-binding affinity and characterizing metal-binding peptides or proteins. The advantages of this method are that it requires a minimal amount of sample peptide and is less time-consuming than $\mathrm{CD}$ or NMR. In this study, we used CS-HPLC with synthetic peptides representing various regions of hPrP to identify not only many $\mathrm{Cu}^{2+}$-binding sites, but also $\mathrm{Zn}^{2+}$ - and $\mathrm{Ni}^{2+}$-binding sites in the middle- and C-terminal domains (Table 3). Our results suggest that $\mathrm{Cu}^{2+}$ may play the most important physiological role, and that $\mathrm{Zn}^{2+}$ - or $\mathrm{Ni}^{2+}$-binding to $\mathrm{PrP}^{\mathrm{C}}$ might contribute to its conformational conversion. Further studies examining conformational conversion and the formation of aggregated peptides are now underway.

Acknowledgement We gratefully thank to Dr. Akikazu Yasuda for technical support in MS analyses.

\section{References}

1) Prusiner S. B., Science, 252, 1515-1522 (1991).

2) Chazot G., Broussolle E., Lapras C., Blättler T., Aguzzi A., Kopp N., Lancet, 347, 1181 (1996).

3) Will R. G., Ironside J. W., Zeidler M., Cousens S. N., Estibeiro K., Alperovitch A., Poser S., Pocchiari M., Hofman A., Smith P. G., Lancet, 347, 921-925 (1996).

4) Prusiner S. B., Science, 278, 245-251 (1997).

5) Pan K. M., Baldwin M., Nguyen J., Gasset M., Serban A., Groth D., Mehlhorn I., Huang Z., Fletterick R. J., Cohen F. E., Proc. Natl. Acad. Sci. U.S.A., 90, 10962-10966 (1993). 
6) Safar J., Roller P. P., Gajdusek D. C., Gibbs C. J. Jr., J. Biol. Chem., 268, 20276-20284 (1993).

7) Cohen F. E., Pan K. M., Huang Z., Baldwin M., Fletterick R. J., Prusiner S. B., Science, 264, 530—531 (1994).

8) Telling G. C., Scott M., Mastrianni J., Gabizon R., Torchia M., Cohen F. E., DeArmond S. J., Prusiner S. B., Cell, 83, 79-90 (1995).

9) Kaneko K., Zulianello L., Scott M., Cooper C. M., Wallace A. C., James T. L., Cohen F. E., Prusiner S. B., Proc. Natl. Acad. Sci. U.S.A., 94, 10069-10074 (1997).

10) Harris D. A., Huber M. T., van Dijken P., Shyng S. L., Chait B. T., Wang R., Biochemistry, 32, 1009-1016 (1993).

11) Zahn R., Liu A., Lührs T., Riek R., von Schroetter C., López García F., Billeter M., Calzolai L., Wider G., Wüthrich K., Proc. Natl. Acad. Sci. U.S.A., 97, 145-150 (2000).

12) Stahl N., Borchelt D. R., Hsiao K., Prusiner S. B., Cell, 51, 229-240 (1987).

13) Forloni G., Angeretti N., Chiesa R., Monzani E., Salmona M., Bugiani O., Tagliavini F., Nature (London), 362, 543—546 (1993).

14) Selvaggini C., De Gioia L., Cantù L., Ghibaudi E., Diomede L., Passerini F., Forloni G., Bugiani O., Tagliavini F., Salmona M., Biochem. Biophys. Res. Commun., 194, 1380-1386 (1993).

15) Brown D. R., J. Neurochem., 73, 1105-1113 (1999).

16) Ettaiche M., Pichot R., Vincent J. P., Chabry J., J. Biol. Chem., 275, 36487-36490 (2000).

17) O’Donovan C. N., Tobin D., Cotter T. G., J. Biol. Chem., 276, 43516 43523 (2001).

18) Brown D. R., Qin K., Herms J. W., Madlung A., Manson J., Strome R., Fraser P. E., Kruck T., von Bohlen A., Schulz-Schaeffer W., Giese A., Westaway D., Kretzschmar H., Nature (London), 390, 684-687 (1997).

19) Miura T., Hori-i A., Takeuchi H., FEBS Lett., 396, 248 -252 (1996).

20) Walter E. D., Chattopadhyay M., Millhauser G. L., Biochemistry, 45, 13083-13092 (2006).

21) Wells M. A., Jackson G. S., Jones S., Hosszu L. L., Craven C. J., Clarke A. R., Collinge J., Waltho J. P., Biochem. J., 399, 435-444 (2006).

22) Wells M. A., Jelinska C., Hosszu L. L., Craven C. J., Clarke A. R., Collinge J., Waltho J. P., Jackson G. S., Biochem. J., 400, 501-510 (2006).

23) Klewpatinond M., Davies P., Bowen S., Brown D. R., Viles J. H., J. Biol. Chem., 283, 1870-1881 (2008).

24) Ronga L., Palladino P., Saviano G., Tancredi T., Benedetti E., Ragone R., Rossi F., Bioinorg. Chem. Appl., 2007, 1-9 (2007).

25) Aronoff-Spencer E., Burns C. S., Avdievich N. I., Gerfen G. J., Peisach J., Antholine W. E., Ball H. L., Cohen F. E., Prusiner S. B., Millhauser G. L., Biochemistry, 39, 13760-13771 (2000).

26) Burns C. S., Aronoff-Spencer E., Legname G., Prusiner S. B., Antho- line W. E., Gerfen G. J., Peisach J., Millhauser G. L., Biochemistry, 42 $6794-6803$ (2003)

27) Bonomo R. P., Imperllizzeri G., Pappalardo G., Rizzarelli E., Tabbì G., Chemistry, 6, 4195-4202 (2000).

28) Viles J. H., Cohen F. E., Prusiner S. B., Goodin D. B., Wright P. E., Dyson H. J., Proc. Natl. Acad. Sci. U.S.A., 96, 2042-2047 (1999).

29) Hornshaw M. P., McDermott J. R., Candy J. M., Lakey J. H., Biochem Biophys. Res. Commun., 214, $993-999$ (1995).

30) Burns C. S., Aronoff-Spencer E., Dunham C. M., Lario P., Avdievich N. I., Antholine W. E., Olmstead M. M., Vrielink A., Gerfen G. J., Peisach J., Scott W. G., Millhauser G. L., Biochemistry, 41, 39914001 (2002).

31) Jackson G. S., Murray I., Hosszu L. L. P., Gibbs N., Walltho J. P., Clarke A. R., Collinge J., Proc. Natl. Acad. Sci. U.S.A., 98, 85328535 (2001).

32) Jones C. E., Klewpatinond M., Abdelraheim S. R., Brown D. R., Viles J. H., J. Mol. Biol., 346, 1393-1407 (2005).

33) Qin K. F., Yang Y., Mastrangelo P., Westaway D., J. Biol. Chem., 277, $1981-1990$ (2002)

34) Whittal R. M., Ball H. L., Cohen F. E., Burlingame A. L., Prusiner S. B., Baldwin M. A., Protein Sci., 9, 332-343 (2000).

35) Hornshaw M. P., McDermott J. R., Candy J. M., Biochem. Biophys. Res. Commun., 207, 621-629 (1995).

36) Miura T., Hori-i A., Mototani H., Takeuchi H., Biochemistry, 38, 11560 -11569 (1999).

37) Miura T., Sasaki S., Toyama A., Takeuchi H., Biochemistry, 44, 8712 - 8720 (2005).

38) Gustiananda M., Haris P. I., Milburn P. J., Gready J. E., FEBS Lett., 512, 38- 42 (2002)

39) Valensin D., Luczkowski M., Mancini F. M., Legowska A., Gaggelli E., Valensin G., Rolka K., Kozlowski H., Dalton Trans., 2004, 1284 1293 (2004).

40) Yu X., Wojciechowski M., Fenselau C., Anal. Chem., 65, 1355-1359 (1993).

41) Lim J., Vachet R. W., Anal. Chem., 76, 3498-3504 (2004).

42) Kojima A., Konishi M., Akizawa T., Peptide Science, 2009, 223-226 (2009).

43) Kojima A., Konishi M., Akizawa T., Bunseki Kagaku, 59, 701-707 (2010).

44) Chang C. D., Meienhofer J., Int. J. Pept. Protein Res., 11, 246-249 (1978).

45) Fields G. B., Noble R. L., Int. J. Pept. Protein Res., 35, 161-214 (1990).

46) Komori K., Konishi M., Maruta Y., Toriba M., Sakai A., Matsuda A., Hori T., Nakatani M., Minamino N., Akizawa T., J. Toxicol. Sci., 31, $157-168$ (2006). 